\title{
Effects of soil and water conservation practices on selected soil physico-chemical properties in Debre-Yakob Micro-Watershed, Northwest Ethiopia
}

\author{
Tigest Alemayehu ${ }^{1}$ and Getachew Fisseha ${ }^{2 *}$ \\ ${ }^{1}$ Amhara Environment, Forest, Wildlife protection \& development Authority, Bahir Dar, Ethiopia \\ ${ }^{2}$ Bahir Dar University, College of Agricutlure and Environmental Sciences, Bahir Dar, Ethiopia
}

\begin{abstract}
Although different types of soil and water conservation practices (SWCPs) were introduced, the sustainable use of these practices is far below expectations, and soil erosion continues to be a severe problem in Ethiopia. Therefore, this study was conducted at Debre Yakobe Micro-Watershed (DYMW), Northwest Ethiopia with the general objective of finding out the effects of SWCPs on selected soil physico-chemical properties. Practices including non-conserved plot in the gentle slope (NCGS), non-conserved plot in the moderate slope (NCMS), bund with Sesbania sesban in the gentle slope (BSGS), bund with Sesbania sesban in the moderate slope (BSMS), bund with pigeon pea (Cajanus cajan) in the gentle slope (BPGS) and bund with pigeon pea in the moderate slope (BPMS) were examined. Soil samples were collected from different land management plots and soil texture while bulk density $(\mathrm{BD})$, $\mathrm{H}$, organic matter $(\mathrm{OM})$, total nitrogen $(\mathrm{TN})$, Available Phosphors (Av.P), and cation exchange capacity $\left(\mathrm{CE}^{p}\right)$ were analyzed in the laboratory. Data were analyzed with the use of one-way analysis of variance and simple regression methods. The results of the study revealed that there is significant difference $(\mathrm{p}<$ 0.05 ) between conserved and non-conserved plots. The conserved plots had the highest soil pH (BPMS) 6.7, OM (BPMS) 3.01\%, TN (BSGS) 0.13\%, Av.P (BPMS) $4.20(\mathrm{ppm})$ and CEC (BSGS) $32.01 \mathrm{cmol}(+) \mathrm{kg}^{-1} \mathrm{but}_{\text {a lower }}$ BD (BPMS) $1.34 \mathrm{~g} \mathrm{~cm}^{-3}$; suggesting that bund accompanied by Sesbania sesban and pigeon pea were found to be effective in improving soil physico-chemical properties in the study area.
\end{abstract}

Key Words: Biological practices, erosion, physical structure, soil properties,

DOI: http://dx.doi.org/10.4314/ejst.v11i1.3

\section{INTRODUCTION}

Erosion, one of the symptoms of unsustainable land management, is a consequential degradation process affecting the soil resource in the entire world (Herweg and Stillhardt, 1999). It is a severe problem in the highlands of Ethiopia, especially in the Amhara Region (Lakew Desta et al., 2006). The result of erosion hazard assessment by Betru Nedasa (2003) indicates that about 6.4 million hectare (ha) or $38 \%$ of the Amhara Region's area suffers from high to very high erosion hazards caused by water. Sheet, rill and gully erosion are commonly observed in the high rainfall areas of East and West Gojam where Nitosols are dominant (Birru Yitaferu, 2003). These types of erosion carry away the fine soil particles of the most fertile topsoil and organic matter (Gete Zeleke, 2000).

Poor soil management and land use practices are the causes of severe soil erosion rates in Ethiopia (Nigussie Haregeweyn and Fekadu Yohannes, 2003). The Debre Yakob Micro-Watershed (DYMW) is one of the watersheds that are facing soil degradation and loss of land productivity in

\footnotetext{
*Corresponding author: gtchwfssh@gmail.com

(C) This is an Open Access article distributed under the terms of the Creative Commons Attribution License (http://creativecommons.org/licenses/CC BY4.0).
} 
the Amhara Region. The farmers in the DYMW suffer from the impacts of severe erosion of their farmlands. To alleviate this problem, a number of policy measures have been undertaken by the government, although their success is highly questionable. More recently, the Ministry of Agriculture and Rural Development (MoARD) of Ethiopia has been engaged in a Productive Safety Net Program (PSNP). Rural communities living in highly degraded areas such as DYMW are involved in soil \& water conservation practices (SWCPs) in the form of Food-For-Work (FFW) under the PSNP

Though SWCPs have significant influence on the fertility of the soil (Tekilu Erkossa and Gezeahegn Ayele, 2003), the effects of these interventions on soil physico-chemical properties were not evaluated in DYMW. Therefore, the objective of this study is to assess the effects of different SWCPs on selected soil physico-chemical properties.

\section{MATERIALS AND METHODS}

\section{Description of the study area}

Debre Yacob Micro-Watershed (DYMW) is located in Mecha district (38 km south west of Bahir Dar city), within Koga watershed between $11^{0} 10^{\prime}$ 06" to $11^{\circ} 24^{\prime} 22^{\prime \prime} \mathrm{N}$ and $32^{\circ} 02^{\prime} 48^{\prime \prime}$ to $37^{\circ} 17^{\prime} 41^{\prime \prime} \mathrm{E}$ (Figure 1). Its area coverage is 325 ha. The average annual rainfall (RF) is $1300 \mathrm{~mm}$ and the mean monthly temperature is $20^{\circ} \mathrm{C}$. The elevation ranges between 2074-2262 meter above sea level (masl), and the slope ranged from flat to very steep. Agroecologically, the micro-watershed is known as Woyna Dega (mid altitude). The total population of the micro-watershed is 975 (male 497 and female 478 ) and the average family size is 4.6 (Fisseha
Moges and Habtemariam Assefa, 2017).

The topography of DYMW is characterized as undulating with some hills and flood plain that form heterogeneity in landscape. The aspect of the watershed is aligned from South West to North East, dissected by two small depressions. The heterogeneity in topography mainly containing undulating and hilly terrain makes the watershed vulnerable to soil erosion. As a result, rill formation and gully development is prominent in many parts of the watershed. In DYMW, around $4 \%$ of the watershed is considered as flat. On the contrary, around $6 \%$ of the watershed is $>50 \%$ slope and totally unfavorable for crop cultivation. A larger proportion of the study area (90\%) falls in the slope ranges of $15 \%$ to $30 \%$ and makes the watershed unsuitable for crop cultivation without SWCP. Agriculture is the main stay of livelihood in the study area. Crop and livestock production are fully integrated and thus the production system can be referred to as crop livestock mixed farming system. Teff (Eragrostis teff), maize (Zea mays), sorghum (Sorghum bicolour) and Millet (Eleusine coracana) are the major crops grown in the micro-watershed.

\section{Method of Data collection for the effects of SWCP on soil physico-chemical properties}

\section{Soil sampling technique}

A reconnaissance survey was carried out to have a general view about the study area. Following the general site selection, representative soil sampling sites were selected both from the farm plots where integrated physical and biological SWCPs have been practiced and plots with no SWCPs (cultivation land adjacent to each structure). In each selected plots, soil samples were collected from the top $0-20 \mathrm{~cm}$ depth at four corners and at the center of a plot to obtain representative composite sample per treatment. 


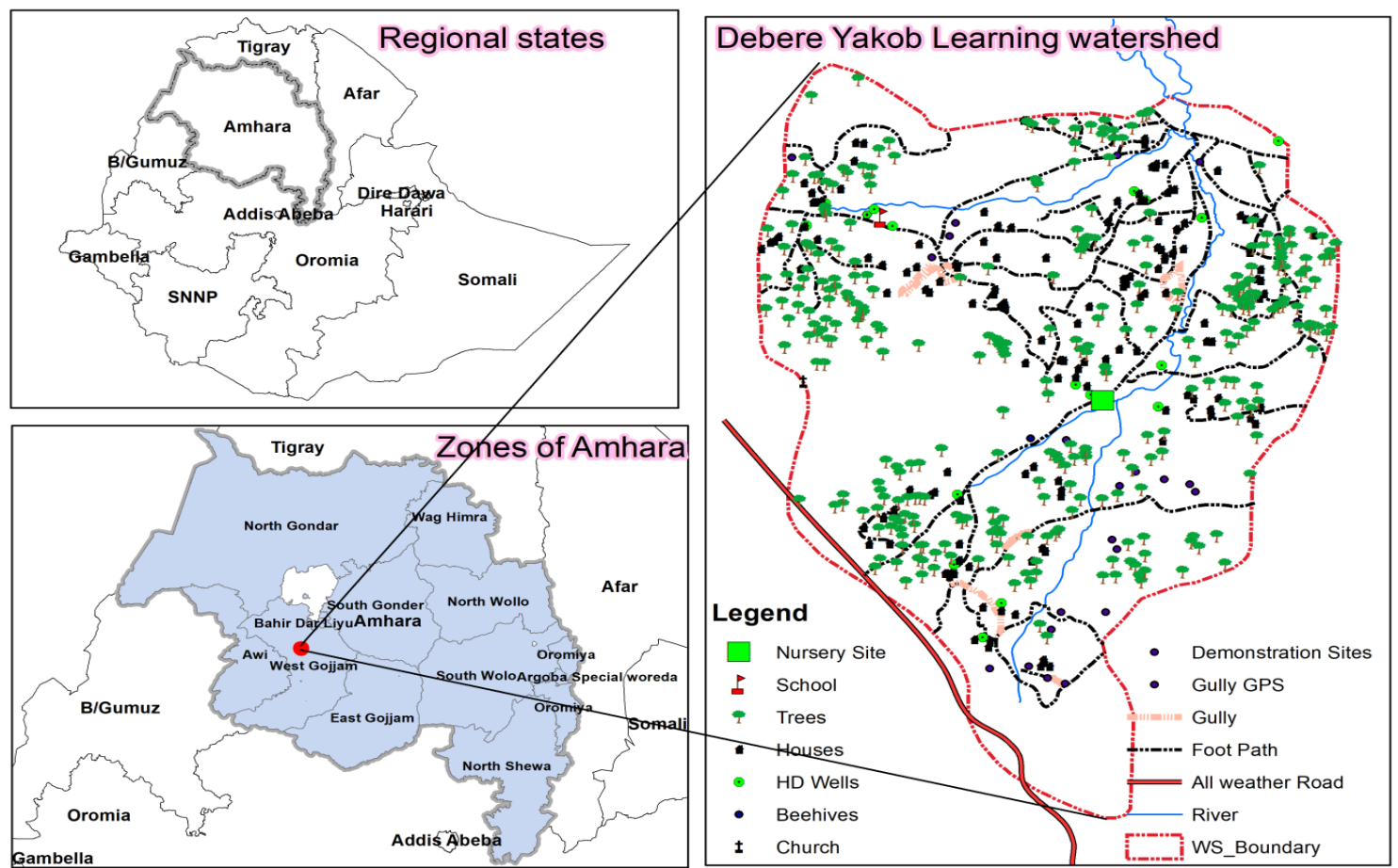

Figure 1. Location map of Debre Yakob Micro-watershed (right) Data from Water \& Land Resource Center (WLRC) website

The experiment had six treatments: Control (nonconserved plots) + gentle slope (8-15\%); Control (non-conserved plots) + Moderate slope (15$30 \%)$; Bund + Sesbania sesban + gentle slope (8$15 \%)$; Bund + Sesbania sesban + Moderate slope $(15-30 \%)$; Bund + pigeon pea (Cajanus cajan) + gentle slope $(8-15 \%)$ and Bund + pigeon pea + Moderate slope (15-30\%). A total of 18 composite soil samples (6 treatments $* 3$ replications $*$ one 0-20 cm depth) were collected in a Randomized Complete Block Design (RCBD) for laboratory analysis. The samples were mixed thoroughly in a plastic bucket to form a composite sample.

\section{Soil Analysis}

The analysis of physical and chemical properties of soil was carried out at Amhara National Regional State (ANRS) Soil Research center. The surface soil samples collected from the study area were air dried, crushed and sieved to pass through $2 \mathrm{~mm}$ sieve for the analysis of $\mathrm{pH}$, particle size distribution, CEC, exchangeable cations and available $\mathrm{P}$ and through $1 \mathrm{~mm}$ sieve for the determinations of organic matter and total nitrogen. Particle size distribution was analyzed by the modified Bouyoucos hydrometer method (Bouyoucos, 1962) using sodium hexametaphasphate as dispersing agent. Bulk density was estimated from undisturbed soil samples collected using core sampler, and the relationship is: Bulk density $\left(\mathrm{g} \cdot \mathrm{cm}^{-3}\right)=$ Oven dry soil mass $(\mathrm{g}) /$ Core volume $\left(\mathrm{cm}^{3}\right)$.

The $\mathrm{pH}$ of the soil was measured potentiometrically using a digital $\mathrm{pH}$ meter in the supernatant suspension of 1: 2.5 soil to liquid ratio where the liquids were water (Van Reeuwijk, 1992). Organic carbon (OC) was determined using: the Walkley and Black (1934) wet digestion method while the OM (\%) was computed by multiplying percent soil organic carbon by a factor of 1.724 (Sahelemedhin and Taye, 2000; Gebeyaw Tilahun, 2007). 
Total Nitrogen (TN) was determined using the Kjeldahl digestion, distillation and titration method (Black, 1965) whereas the Olsen's extraction method Olsen et al. (1954) was used for available phosphors extraction under wide range of $\mathrm{pH}$ (Landon, 1991; Tekalign Mamo and Haque, 1991).

Cation exchange capacity (CEC) was determined from ammonium acetate saturated soil samples that were subsequently replaced by $\mathrm{Na}$ from a percolated sodium chloride solution. The excess salt was removed by washing with alcohol and the ammonium ion that was displaced by sodium was measured using Kjeldahl procedure (Chapman, 1965) and reported as CEC.

\section{Method of Data analysis}

The data obtained from laboratory and field measurements were analyzed using one way analysis of variance (ANOVA) using SPSS, 16 (2007). Mean comparisons between treatments were conducted using LSD pos hock test method and linear regression analysis using SAS 9.1.3 to quantify some correlations between soil properties.

\section{RESULTS AND DISCUSSION}

\section{Effect of Soil and Water Conservation}

\section{Practices on Soil Physical Properties}

Soil texture: Table 1 shows that there was significant difference between sand and clay content ( $p<0.05, \mathrm{R} 2$ of 0.68 for sand and 0.71 for clay). Specifically, among the treatments, soils of non-conserved plot had the highest mean value of clay and the lowest sand $(\mathrm{p}<0.05)$ content. There was no significant difference among treatments that were managed through different SWCPs.

Mulugeta Demelash and Karl (2010) confirmed that soils of non-conserved land had the highest percentage of mean value of clay and silt and the lowest percentage of sand due to the exposure of soil by tillage to soil erosion by water that ultimately exposes the subsoil, which is naturally high in clay content. Desta Gebremichael et al. (2005) pointed out that age of the bund had a significant impact on lowering the percentage of clay fraction as it lowered slope gradient, reduced soil erosion and increased soil $\mathrm{OM}$ with relative soil depth change.

Bund stabilized with pigeon pea in the gentle slope showed significant $(p<0.05)$ means variation with bund stabilized with Sesbania sesban in the gentle slope. Table 1 indicates that though there was significant soil texture difference between conserved and non-conserved farmlands, the texture class showed that all treatments were clay soils.

\section{Bulk Density}

The non-conserved plot was found to exhibit significantly the highest mean value of bulk density than plots treated with SWCPs (Table1). The significant effect of SWCPs on bulk density was observed $\left(1.35 \mathrm{~g} / \mathrm{cm}^{3}\right)$ in the bund + pigeon pea + gentle slope plot where bulk density was higher in the non-conserved plot $\left(1.77 \mathrm{~g} / \mathrm{cm}^{3}\right)$. This could be attributed to the presence of significantly higher organic matter as a result of conservation practices. This finding agrees with the findings of Abay Challa et al. (2016); Mulugeta Demelash and Karl (2010) who studied the effects SWC measures on selected soil properties in central and northwestern highlands of Ethiopia. 


\begin{tabular}{|c|c|c|c|c|c|}
\hline \multirow[b]{2}{*}{ Treatments } & \multicolumn{3}{|c|}{ Soil texture } & \multirow{2}{*}{$\begin{array}{l}\text { Texture } \\
\text { class }\end{array}$} & \multirow{2}{*}{$\begin{array}{l}\begin{array}{l}\text { Bulk } \\
\text { Density }\end{array} \\
\left(\mathrm{g} \mathrm{cm}^{-3}\right)\end{array}$} \\
\hline & $\begin{array}{l}\text { Sand } \\
(\%)\end{array}$ & $\begin{array}{l}\text { Silt } \\
(\%)\end{array}$ & $\begin{array}{l}\text { Clay } \\
(\%)\end{array}$ & & \\
\hline Control (non-conserved plots) + gentle slope $(\mathrm{CA})$ & 16.95 & 19.61 & 63.44 & Clay & 1.77 \\
\hline Control (non-conserved plots) + moderate slope $(\mathrm{CB})$ & 12.95 & 17.28 & 69.77 & Clay & 1.55 \\
\hline Bund + Sesbania sesban + gentle slope(SA) & 21.28 & 25.28 & 53.44 & Clay & 1.64 \\
\hline Bund + Sesbania sesban + moderate slope(SB) & 20.28 & 21.95 & 58.11 & Clay & 1.54 \\
\hline Bund + pigeon pea + gentle slope $(\mathrm{PA})$ & 20.28 & 23.61 & 54.77 & Clay & 1.35 \\
\hline Bund + pigeon pea + moderate slope $(\mathrm{PB})$ & 19.95 & 23.28 & 56.77 & Clay & 1.62 \\
\hline $\operatorname{LSD}(0.05)$ & $0.02 *$ & $0.0 * *$ & $0.01 * *$ & & $0.01 * *$ \\
\hline $\mathrm{CV}$ & 19.22 & 19.4 & 12.10 & & 16.20 \\
\hline
\end{tabular}

Significant at the 0.05 level

\section{Effect of Soil and Water Conservation Practices on Soil Chemical Properties}

Soil Organic Matter: Soil organic Matter (SOM) showed significant variation $\mathrm{R}^{2}=0.87(\mathrm{p}<0.05)$ with respect to treatments. The SOM content under the non-conserved plots was significantly lower than all the other treatments (Table 2). The significantly lowest SOM occurred in nonconserved plot $(2.4 \%)$, while the highest $(3.01 \%)$ SOM showed in the plot which was conserved with Bund + pigeon pea + gentle slope (Table 2)

The result agrees with the finding of Yihenew Gebreselassie et al. (2009), Mulugeta Demelash and Karl (2010), Tadele Amedemariam et al. (2011) Worku Hailu et al. (2012) and Abay Challa et al. (2016) in that the non-conserved lands had significantly lower SOM as compared to the conserved lands treated with different conservation measures.
Total Nitrogen: Results of the experiment presented in Table 2 indicate that there was a significant difference in percentage of total nitrogen between treatments $(p<0.05)$. Analysis of variance also revealed that total nitrogen had no significant variation among conserved treatments. The total nitrogen content in soils under non-conserved plots was significantly lower $(0.06 \%)$ than the content under conserved plots $(0.13 \%)$. Similarly Abay Challa et al. (2016), Worku Hailu et al. (2012) and Mulugeta Demelash and Karl (2010) found higher total nitrogen content in farm plots with physical conservation measures as compared to the nonconserved lands.

The significant difference in the total nitrogen content among conserved and non-conserved treatments could be SWC structures stabilized with nitrogen fixing plants. According to Bot and Benites (2005), organic matter accumulation is 
Table 2: Effects of SWC measures on selected soil chemical properties

\begin{tabular}{llllll}
\hline \multirow{2}{*}{ Treatments } & $\begin{array}{l}\mathrm{P} \\
(1: 2.5)\end{array}$ & $\begin{array}{l}\mathrm{OM} \\
(\%)\end{array}$ & $\begin{array}{c}\mathrm{TN} \\
(\%)\end{array}$ & $\begin{array}{c}\mathrm{Av} \text {-P } \\
(\mathrm{ppm})\end{array}$ & $\begin{array}{l}\mathrm{CEC} \\
(\mathrm{cmol}+\mathrm{kg})\end{array}$ \\
\hline Non-conserved plots + gentle slope (NCGS) & 6.36 & 2.40 & 0.09 & 3.38 & 27.31 \\
Non-conserved plots + moderate slope (NCMS) & 6.03 & 2.63 & 0.11 & 3.45 & 31.27 \\
Bund + Sesbania sesban + gentle slope (BSGS) & 6.49 & 2.48 & 0.12 & 3.72 & 30.79 \\
Bund + Sesbania sesban + moderate slope (BSMS) & 6.17 & 2.74 & 0.11 & 3.19 & 32.01 \\
Bund + pigeon pea + gentle slope (BPMS) & 6.66 & 3.01 & 0.11 & 3.16 & 30.17 \\
Bund + pigeon pea + moderate slope (BPMS) & 6.10 & 2.66 & 0.11 & 4.20 & 28.56 \\
\hline LSD $(0.05)$ & $0.00 * *$ & $0.01 * *$ & $0.03 *$ & $0.04 *$ & $0.01 * *$ \\
\hline SD & 0.18 & 0.38 & 0.03 & 1.28 & 3.88 \\
\hline SEM $( \pm)$ & 0.17 & 0.22 & 0.02 & 0.74 & 2.24 \\
\hline CV & 2.81 & 15.01 & 28.62 & 34.90 & 12.81 \\
\hline
\end{tabular}

C.V $=$ Coefficient of variation; $\mathrm{LSD}=$ Least significant difference; $* *=$ Significant at the 0.01 level; $\quad *=$ Significant at the 0.05 level NCGS $=$ Control (non-conserved plots) + gentle slope

often favored at the bottom or lower slope of hills of non-conserved plots for two reasons: (i) they are wetter than at mid- or upper-slope positions, (ii) organic matter could be transported to the lowest point in the landscape through run off and erosion.

Soil ${ }_{\mathrm{P}} \mathrm{H}$ : The mean of soil $\mathrm{pH}$ significantly varied between treatments $(\mathrm{P} \leq 0.05)$. The overall ${ }_{\mathrm{p}} \mathrm{H}$ value of the study area ranged between 6.03 and 6.66. It was lower in moderate slope control farm land and higher in the bund found at gentle slope stabilized with pigeon pea (Table 2). Though there were significant differences between treatments with gentle and moderate slope gradients, the soil ${ }_{\mathrm{p}} \mathrm{H}$ was within the preferred range for most agricultural practice, 5.5-7.0 ${ }_{\mathrm{P}} \mathrm{H}$ (Brady and Weil, 2002).

CEC: The analysis of variance showed that the overall mean CEC values did not significantly vary $(\mathrm{p}<0.05)$ with respect to treatments and slope gradients (Table 2). The variations between treatments as well as slope gradients were very small. This could be attributed to the soil texture, particularly to clay. This is in line with Gebeyehu Tilahun (2007) who reported that CEC is significantly and positively correlated with clay. In surface horizons of mineral soils, higher $\mathrm{OM}$ and clay contents significantly contribute to the CEC, while in the subsoil particularly where Bt horizon exist, more CEC is contributed by the clay fractions than by $\mathrm{OM}$ due to the decline of $\mathrm{OM}$ with profile depth (Foth, 1990; Brady and Weil, 2002). These finer soils (clay) are negatively-charged particles. For this reason, they can attract, hold and release positively-charged nutrient particles (cations). As a result, higher clay containing soils can hold more exchangeable cations than soils having low clay (Alemayehu Assefa, 2007). Therefore, this could be the reason for the insignificant difference between treatments among CEC values.

The CEC values $(\mathrm{cmol}+/ \mathrm{kg})$ in the study area ranged from 28.76 to 31.70 among the treatment and the mean difference among slope gradients 
ranged from 0.86 to 2.14. The mean CEC values were higher in gentle slopes and lower in moderate slopes (Table 5). According to Landon (1991), the top soils having CEC of $>25,15-25 \mathrm{cmol}(+) / \mathrm{kg}$, $5-15 \mathrm{cmol}(+) / \mathrm{kg}$ and $<5 \mathrm{cmol}(+) / \mathrm{kg}$ are classified as high, medium, low and very low, respectively. Based on the above ratings, both conserved and non-conserved treatments in the study area qualify to the higher status of CEC (Table 2).

Available phosphorus: The result (Table 6) also indicates that available phosphorous did not significantly $(\mathrm{p}<0.05)$ vary both with the treatments and slope gradients. The mean value of available phosphorus within treatments as well as slope gradients showed a small difference. A relative higher mean value of available phosphorus is observed in non-conserved land in the gentle slope while lower value of available phosphorus showed in bund stabilized with pigeon pea in gentle slope. The insignificant difference between conserved and non-conserved farm plots could be attributed to the following factors. The laboratory analysis revealed that the texture of the sampled soils in the study area is mainly clay. This could limit aeration which is crucial for micro-organisms living in the soil to breakdown organic matter. Moreover, available phosphorus is low because $\mathrm{P}$ is quickly fixed in soil, and it is not available for plants due to its immobility. The low record of available phosphorus content could be due to the fact that the parent material in which the considered soils were derived could be poor in phosphorus (Alemayehu Assefa, 2007).

\section{Effects of SWC Measures on Crop Yields}

In Table 6, the conserved farm plots had significantly higher mean crop yield compared to non-conserved treatments. According to Shimelse Damene (2012) the SWC structures are also not completely sediment proof, and the effectiveness of the structures varies with slope and structure type. For example, Herweg and Ludi (1999) reported $0.5 \mathrm{t} / \mathrm{ha}$ to $3.3 \mathrm{t} / \mathrm{ha}$ annual soil loss under different SWC structures at his study area. All the above processes facilitate soil nutrient export out of the system, which in turn influence the measured soil fertility states of the terraces over time.

Therefore, this crop yield difference might be due to the fact that plants could consume the available phosphorus in the conserved sampled farm plots. Gebeyaw Tilahun (2007) also confirmed that the lower phosphorus content in the forest land may be because the forest vegetation with their larger biomass absorb larger amount of available phosphorus that would cause phosphorus depletion particularly below the surface $(0-20 \mathrm{~cm})$ layer of the soil. In line with this, the phosphorus content of the surface soils under the grazing and the cultivated lands that are explored by plant roots had lower availability phosphorus compared to the subsoil layers.

Table 3: Effects of SWC measures on crop yield

\begin{tabular}{lll}
\hline & \multicolumn{2}{l}{ Crop Yield (Kg/ha) } \\
\cline { 2 - 3 } \multicolumn{1}{c}{ Treatments } & Maize & Finger Millet \\
\hline Control (non-conserved) & $2946^{\mathrm{b}}$ & $1200^{\mathrm{b}}$ \\
Bund stabilized with Sesbania sesban & $4344^{\mathrm{a}}$ & $1716^{\mathrm{a}}$ \\
Bund stabilized with pigeon pea & $4484^{\mathrm{a}}$ & $1856^{\mathrm{a}}$ \\
\hline
\end{tabular}

Note: Means within column followed by different letters are significantly different at $(\mathrm{p}<0.05)$. 


\section{CONCLUSION}

The effect of SWC practices on selected soil properties in Debre Yakob watershed was assessed by using laboratory analysis of soil samples. The results of the study revealed that there is significant difference between conserved and non-conserved plots. The conserved plots had the highest soil ${ }_{\mathrm{p}} \mathrm{H}, \mathrm{OM}, \mathrm{TN}, \mathrm{Av} . \mathrm{P}$ and CEC but a lower BD; suggesting that structural conservation practices (bund) accompanied by plant species (Sesbania sesban and pigeon pea) are effective in improving soil physico-chemical properties in the study area. Therefore, SWCPs play an essential role for erosion control and for sustainable watershed management.

\section{REFERENCES}

Alemayehu Assefa. (2007). Impact of terrace development and management on soil properties in Anjeni Area, West Gojam. MSc thesis. Addis Ababa University department of Geography and Environmental Studies. 36p.

Abay Challa, Abdu Abdelkadir and Tefera Mengistu. (2016). Effects of Graded Stone Bunds on Selected Soil Properties in the Central Highlands of Ethiopia (2016). International Journal of Natural Resource Ecology and Management 1(2): 42-50.

Betru Nedasa. (2003). Soil and water conservation program in the Amhara National Regional State. Tilahun Amede (ed.). In: Proceedings of the Natural Resource Management Conference, Natural Resources Degradation and Environmental Concerns in the Amhara National Regional State: Impact on food security. July 24-26, 2002, Bahir Dar, Ethiopia.

Birru Yitaferu. (2003). Soil and water conservation technologies, transfer and adoption by the smallholder farmers in the Amhara Region. Tilahun Amede (ed.). In: Proceedings of the Natural Resource Management Conference, Natural Resources Degradation and Environmental Concerns in the Amhara National Regional State: Impact on food security. July 24-26, 2002, Bahir Dar, Ethiopia

Black, C.A. (1965). Methods of soil analysis, Part I, American Society of Agronomy. Madison, Wisconsin, USA. Pp 1572.

Bot, A and Benites, J. (2005). The Importance of Soil Organic Matter - Key to Drought Resistant Soil and Sustained Food and Production. FAO, Rome, p. 78.

Bouyoucos, G.J. (1962). Hydrometer method improvement for making particle size analysis of soils. Agronomy Journal. 54: 464-464

Brady, N.C and Weil, R.R. (2002). The Nature and Properties of Soils. 13th Ed. Prentice- Hall Inc., New Jersey, USA. 960p.

Chapman, H.D. (1965). Cation exchange capacity. C.A. Black, L.E. Ensminger and F.E.Clark (Eds). In: Methods of soil analysis. Agronomy. 9: 891901. Am. Soc. Agro., Inc., Madison, Wisconsin

Desta Gebremichael, Nyssen, J., Mitiku Haile, Gover, G and Moeyersons, J. (2005). Effectiveness of stone bunds in controlling soil erosion on crop land in the Tigray Highlands, Northen Ethiopia. Soil use Manage 21: 287-297. 
Fisseha Moges and Habtemariam Assefa. (2017). Chicken production and marketing systems in four selected learning watersheds of Amhara region, Ethiopia. Radix International Journal of Research in Social Sciences 6(4):

Foth, H.D. (1990). Fundamentals of soil science, 8th Ed. John Wiley and Sons, Inc., New York, USA. 360p.

Gebeyaw Tilahun. (2007). Soil fertility status as influenced by different land uses in Maybar areas of south Wello zone, North Ethiopia. MSc Thesis, Haramaya University, Ethiopia.

Gete Zeleke. (2000). Landscape dynamics and soil erosion process modeling in the

Northwestern Ethiopian highlands. PhD Dissertation, Bernensia, Berne, Switzerland.

Herweg, K and Ludi, E. (1999). The performance of selected soil and water conservation measurescase studies from Ethiopia and Eritrea. Catena 36(1):99-114.

Herweg, K and Stillhardt B. (1999). The variability of soil erosion in the highlands of Ethiopia and Eritrea, Research Report (42). Soil Conservation Research

Lakew Desta, Menale Kassie, Benin S and Pende, J. (2006). Land degradation and strategies for sustainable development in the Ethiopian high lands: Amhara Region, Socio- economic and policy Research Working Paper 32. p14. ILRI, Nairobi, Kenya.

Landon, J.R. (Ed.). (1991). Booker tropical soil manual: A Handbook for Soil Survey and Agricultural Land Evaluation in the Tropics and Subtropics. Longman Scientific and Technical, Essex, New York. 474p.
Mulugeta Demelash and Karl, S. (2010). Assessment of integrated soil \& water conservation measures on key soil properties in South Gondar, Northwestern Highlands of Ethiopia. Journal of science and Environmental management 1(7): 164-176.

Nigussie Haregeweyn and Fekadu Yohannes. (2003). Testing and evaluation of the agricultural non-point source pollution model (AGNPS) on Augucho Catchment's, Western Hararghe, Ethiopia. Agricultural ecosystem Environment, 99(1-3): 201-212.

Olsen, S.R., Cole C.V. Watanable, F.S and Dean L.A. (1954). Estimation of variable phosphorus in soil by extraction with sodium bicarbonate. USDA Circular. 939: 1-19.

Sahlemedhin Sertsu and Taye Bekele. (2000). Procedures for soil and plant analysis.

Technical paper No. 74. National Soil Research Centre, Ethiopian Agricultural Research Organization, Addis Ababa, Ethiopia.110p.

Shimeles Damene. (2012). Effectiveness of soil and water conservation measures for landrestoration in the Wello area, northern Ethiopian highlands. $\mathrm{PhD}$ desrtation, Ecology and Development Series No. 89, 2012p.

Tadele Amedemariam, Yihenew G. Selassie, Mitiku Haile and Yamoh. C. (2011). Effect of Soil and Water Conservation Measures on Selected Soil Physical and Chemical Properties and Barley (Hordeum spp.) Yield. Journal of Environmental Science and Engineering 5: 1483-1495.

Tekalign Mamo and Haque, I. (1991). Phosphorus of some Ethiopian soils. 111. Evaluation of some soil test methods for available phosphorus. Tropial Agriculture. 68(1): 51-56. 
Teklu Erkossa and Gezeahegn Ayele. (2003). Indigenous knowledge and practices for soil and water management in East Wollega Ethiopia. Conference on International agricultural Research and development. Göttingen.

Van Reeuwijk, L.P. (1992). Procedures for soil analysis, 3rd Ed. International Soil Reference and Information Center (ISRIC), Wageningen, the Netherlands. Pp 34.

Walkley, A and Black, CA. (1934). An examination of Degtjareff methods for determining soil organic matter and the proposed modifications of the chromic acid titration method. Soil Science 37:29-38.

Worku Hailu, Awdenegest Moges and Fantaw Yimer. (2012). The Effects of Fanya juu Soil Conservation Structure on Selected Soil Physical $\&$ Chemical Properties: the Case of Goromti Watershed, Western Ethiopia

Yihenew Gebreselassie, Tadele Amdemariam, Mitiku Haile and Yamoah ,C. (2009). Lessons from upstream soil conservation measures to mitigate soil erosion and its impact on upstream and downstream users of the Nile River. International Water Management Institute. Pp.170-183. 